Jurnal Keperawatan Padjadjaran

ISSN 2338-5324 (print)

ISSN 2442-7276 (online)

Online di http://jkp.fkep.unpad.ac.id

DOI : $10.24198 / \mathrm{jkp}$

\title{
Factors Related to The Needs of Parents Having School Age Thalassemic Children
}

\author{
Henny Suzana Mediani, Anita Tiara, Ai Mardhiyah \\ Faculty of Nursing Universitas Padjadjaran, Bandung, Indonesia \\ Corresponding email: henny.mediani@unpad.ac.id
}

Submitted: 30-01-2019 Accepted: 06-08-2019 Published: 10-08-2019

\begin{abstract}
Thalassemia is a major genetic blood disorder that has negative impacts on thalassemic children and their family. The needs of parents while caring for thalassemia children are important matters because the failure of meeting needs of parents may affect their mental and physical health. Yet, litle is known about factors that meeting the needs of thalasemic child parents. The study aim was to identify factors that correlate with the needs of parents having a school age thalassemic child in west jave province. This research used correlational analytic with cross sectional approach. The population in this study were parents of school-age children with thalassemia major totaling 136 people using the total sampling method. Data were analyzed with bivariate using chi square and biserial points. Then a multivariate analysis used logistic regression. The results showed the age of parents related to information $(\mathrm{p}=$ $0.005)$ and professional $(p=0.004)$, parent gender related to information $(p=0.000)$, professional $(p=0.017)$, social $(p=0.035)$, financial $(p=0.023)$ and spiritual $(p=0.009)$. Parental education is related to information $(p=0.000)$, social $(p=0.005)$, emotional $(p=0.000)$, financial $(p=0.016)$ and spiritual $(p=0.001)$. Parent income is related to information $(0.000)$, social $(p=0.006)$, emotional $(p=0.000)$, financial $(p=0.003)$ and spiritual $(p=0.004)$. The number of thalassemia major children is related to emotional $(p=0.015)$ and financial $(p=0.013)$. Parental needs are related to several factors. The importance of increasing the role of nurses as educators and consultants and helping parents find sources of spiritual, emotional and financial support for parents of school-age children with thalassemia.
\end{abstract}

Keywords: Needs, parents, school-age children, thalassemia major. 
Henny Suzana Mediani: Factors Related to The Needs of Patients Having School Age Thalassemic

\section{Introduction}

Thalassemia is an inherited hematological single gene disorder leading to anemia in affected children in the world that represents a major public concern in Southeast Asia, including Indonesia (Galanello \& Origa, 2010; Mediani, Nurhidayah, Mardhiyah \& Panigoro, 2017; Viprakasit Origa, \& Fucharoen., 2014). According to the Indonesian Thalassemia Foundation-the central association of parents of thalassemia children that Indonesia is one of the countries with a high prevalence of thalassemia with the carriers of thalassemia around 5-10\% and it is estimated that every year 500-600 babies are born with thalassemia. In 2015, thalassemia cases in Indonesia reached 7,029 cases. Meanwhile, cases of thalassemia in west java is the highest in Indonesia, it reachs $42 \%$ cases or 3,300 in early January 2016 (Kemenkes., 2017).

Thalassemia consists of minor thalassemia or the carrier and thalassemia major (Galanello \& Origa, 2010; Regar, 2009). Thalassemia major is obtained genetically which is characterized by the reduction or absence of beta globin synthesis which results in the destruction of red blood cells in the bone marrow or spleen therefore, decreasing $\mathrm{Hb}$, red blood cell production and anemia (Galanello \& Origa, 2010; Marcdante, Kliegman, Jenson \& Behrman, 2011).

When a child is diagnosed with thalassemia, parents start a new routine, are preoccupied with scheduling treatment, seeking information and learning about the treatment process, changing patterns of work, income, and responsibilities in the family and providing emotional support to children and other family members (Klassen et al., 2011; Pelentsov, Fielder \& Esterman., 2015). Parents as caregivers should fulfil their duties of caring for school-aged children with thalassemia who need care for life (Astarani \& Siburian., 2016; Pouraboli et al., 2015; Potts \& Mandleco, 2007), but on the other hand they also need to meet the other children's needs, family members' needs and their own needs so that it requires great time, efforts and sacrifice (Astarani \& Siburian, 2016; Klassen et al., 2011).

Need is an important thing and satisfaction is an indicator when needs have been fulfilled or not, in other words, someone will feel satisfied once they met their needs (Kim, Kashy, Spillers \& Evans, 2010). Failure to fulfil needs results in an imbalance in one's condition that will affect mental and physical health (Asmadi, 2008; Winstanley, Simpson, Tate, \& Myles, 2006). The health problems occurred in parents will affect the care of their children with thalassemia and lead an impact on children's health (Mediani et al., 2017; Wacharasin, Phaktoop \& Sananreangsak, 2015), besides that, children also spend more time at home with parents compared to hospitals so parents can provide care better for their children (Wilder, 2010). The needs of parents in school-aged children with thalassemia are associated with longterm complications, blood transfusions and iron chelation (Mediani et al., 2017; Shosha, 2014).

The needs of information that needed by parents related to congenital blood disorders (carrier) in parents and how the scheme devolves to children, the vulnerability of thalassemia and managing side effects of transfusions such as iron overload. The needs of support are expected to come from family, friends, neighbours, teachers, nurses and physicians' supports regarding care, treatment and follow-up care (Mediani et al., 2017). Then the needs of financial are needed relating to thalassemia treatment: transportation costs, hospital admission costs when the child is sick, and costs while leaving his job to accompany his child (Mediani et al., 2017; Shosha, 2014). The needs of emotional of parents are related to the children's health condition, the severity of the disease and the responsibilities of parents. They live in fear and helplessness because their child's illness will worsen over time (Pelentsov, Dip, Laws \& Esterman, 2015). The needs of spiritual are another urge for parents (Pelentsov, Dip, Laws \& Esterman., 2015; Sujana, Fatimah $\&$ Hidayati, 2017). The needs of spiritual of parents concerned about the urge for meaning and purpose while caring for the child. Some parents feel unable to get involved with religious rituals and practices because of their child's illness, resulting in a crisis of faith.

Sociodemographic characteristics are strong predictors of not meeting the needs of 


\section{Henny Suzana Mediani: Factors Related to The Needs of Patients Having School Age Thalassemic}

parents and must be considered in developing interventions to help parents meet their needs (Kim, Kashy, Spillers, Evans, 2010). Sociodemography means a description of the population as a whole or group and is categorized based on certain characteristics, such as age, socio-economy and distribution of residence (Adioetomo, 2010). Some literature showed that the sociodemographic characteristics of parents related to the needs of parents including age, gender, education level and income (Kim, Kashy, Spillers \& Evans, 2010) and the number of children with thalassemia (Habeeb et al., 2015; Ishfaq, Naeem \& Ali, 2013). According to Kerr (2008) and Pelentsov, Dip, Laws and Esterman (2015) based on the concept of supportive care needs, this needs are influenced by age, gender, education, economic status, family support, culture and religion. The Child's characteristic related to parents' needs is time period of being diagnosed (Golics et al., 2013).

Family involvement in nursing care is part of the philosophy of pediatric nursing, namely family-centred care (Kyle \& Carman, 2014). Family-centred care is able to improve the quality of life of children with thalassemia (Nafafi, Borhani, Rabari \& Sabzevari, 2011). Family-centred care is used as a standard of pediatric nursing practice that involves families/parents in caring for children (Kuo et al, 2012; Suza, 2017).

As a pediatric nurse who provides nursing care, it is necessary to understand the factors related to the needs of parents in order to provide appropriate interventions according to the parents' needs of school-aged children with thalassemia. If the nursing interventions provided are not in accordance with the parents' needs, parents will experience emotional distress and have difficulty caring for their child (Fitch, 2008).

\section{The Aim Of The Study}

The aim of the study was to analyze factors that relate to the needs of parents having school age thalassemic children at 4 government hospitals in West Java Province.

\section{Method}

This study used a quantitative method with correlational analytic research design and a cross-sectional approach. The cross-sectional study is observing the subject of the study once and carrying out the variable measurement at the same time (Keller \& Kelvin., 2012). The study used the total sampling method to choose the overall sampling of the population (Sugiyono, 2013). The sample in this study were all 136 parents of schoolaged children (6-12 years) with thalassemia major: 40 respondents from Distric Hospital 45 Kuningan; 20 people from Gunung Jati Cirebon Hospital, 23 parents from Majalengka Distric Hospital and 53 people from Sumedang Distric Hospital. Sample selection based on inclusion criteria that were parents who accompany their thalassemic children for having thallasemic treatment in those hospitals, parents who can read and write, parents with children who undergo transfusions and iron chelation treatment. While, the exclusion criteria in this current study was parents with children who have undergone splenectomy.

Data collection was carried out in 4 govenment distric hospitals in West Java Province for five weeks starting on July 3rd, 2018 until August 21st 2018. Data coolection method used in this current study was questionnaires which focused on the needs of information, emotional, and spiritual using supportive care need instrument modified from Kerr et al. (2007) and the needs of professional from Pelentsov et al. (2016) while social and financial needs using the family need survey instrument. Meanwhile, the factors studied were the parents' age, gender, education, parent income, number of thalassemia major children and the time period of being diagnosed.

Data analysis were processed by using the computer software. Several data analysis techniques used in this study: 1) Univariate analysis was performed to obtain the frequency from each variable, 2) Bivariate analysis was conducted to determine the significance of the relationship between each independent variable and one dependent variable using the chi-square test and biserial points, and 3) Multivariate analysis used logistic regression due to variables in this study is categoric.

This study was approved by the Health 
Henny Suzana Mediani: Factors Related to The Needs of Patients Having School Age Thalassemic

Research Ethics Committee of the Faculty of Medicine, Universitas Padjadjaran. The ethics committee has reviewed the study protocol and determined that it adheres to ethical principles. Ethical approval number is 514/UN6.KEP/EC/2018. Permission for conducting this study was obtained from dean faculty of nursing and directors of the hospitals. All participants were asked to complete a consent form. Confidentiality was warranted by restricting access to the names of participants and demogarpahic details were separated from other data to ensure that respondents could not be identified. Only the researchers can access to the raw data.

\section{Results}

Table 1 Characteristics of Parents of School-Aged Children with Thalassemia Major in West Java

\begin{tabular}{lc}
\hline \multicolumn{1}{c}{ Variable } & $\mathbf{f}(\mathbf{\%})$ \\
\hline Age (years old) & $42(30.1)$ \\
Late Adolescent (17-25 years old) & $71(52.2)$ \\
Adults (26-45 years old) & $24(17.6)$ \\
Early Elderly (46-55 years old) & \\
Gender & $34(25.0)$ \\
Male & $102(75.0)$ \\
Female & \\
Education & $79(58.1)$ \\
Primary (Elementery School/Junior High School) & $36(26.5)$ \\
Middle (Senior High School/of the same level) & $21(15.4)$ \\
High (College) & \\
Income & $97((71.3)$ \\
$<$ Regional Minimum Wage (IDR 2,250,000) & $39(28.7)$ \\
$>$ Regional Minimum Wage (IDR 2,250,000) & \\
The Number of Thalasemia Major Children & $110(80.9)$ \\
1 child & $26(19.1)$ \\
\hline 1 child &
\end{tabular}

Table 2 Characteristics of School-Aged Children with Thalassemia Major in West Java

\begin{tabular}{cccc}
\hline Variable & mean $\pm \mathbf{S D}$ & $\min$ & $\max$ \\
\hline Length of time diagnosed & $7.5 \pm 2.85$ & 1.00 & 12.0 \\
\hline
\end{tabular}

Table 3 The Needs of Parents of School-Aged Children with Thalassemia Major in West Java

\begin{tabular}{lcccc}
\hline \multirow{2}{*}{ The parent's needs } & \multicolumn{3}{c}{ Low } & \multicolumn{3}{c}{ High } \\
\cline { 2 - 5 } & f & \% & f & \% \\
\hline Need of Spiritual & 56 & 41.2 & 80 & 58.8 \\
Need of Social & 57 & 41.9 & 79 & 58.1 \\
Need of Information & 60 & 44.1 & 76 & 55.9 \\
Need of Emotional & 63 & 46.3 & 73 & 53.7 \\
Need of Finansial & 69 & 50.7 & 67 & 49.3 \\
Need of Professional & 74 & 54.4 & 62 & 45.6 \\
\hline
\end{tabular}


Henny Suzana Mediani: Factors Related to The Needs of Patients Having School Age Thalassemic

Table 4 Relationship of Parents' Age, Gender, Education, Income, the Number of Thalassemia Major Children with Parents' Needs of School-Aged Thalassemia Major Children in West Java

\begin{tabular}{|c|c|c|c|c|c|c|}
\hline \multirow[t]{3}{*}{ Variable } & \multicolumn{6}{|c|}{ The parent's needs } \\
\hline & Information & Emotional & Professional & Financial & Social & Spiritual \\
\hline & P-value & P-value & P-value & P-value & P-value & P-value \\
\hline $\begin{array}{l}\text { Age } \\
17-25 \text { years old } \\
26-45 \text { years old } \\
46-55 \text { years old }\end{array}$ & 0.005 & 0.213 & 0.004 & 0.683 & 0.320 & 0.168 \\
\hline $\begin{array}{l}\text { Gender } \\
\text { Male } \\
\text { Female }\end{array}$ & 0.000 & 0.136 & 0.017 & 0.023 & 0.035 & 0.009 \\
\hline $\begin{array}{l}\text { Education } \\
\text { Elementery } \\
\text { Midle } \\
\text { High }\end{array}$ & 0.000 & 0.000 & 0.794 & 0.016 & 0.005 & 0.001 \\
\hline $\begin{array}{l}\text { Financial } \\
<\text { UMR } \\
\geq \text { UMR }\end{array}$ & 0.000 & 0.000 & 0.103 & 0.003 & 0.006 & 0.004 \\
\hline $\begin{array}{l}\text { The Number of } \\
\text { Thalassemia Major } \\
\text { Children } \\
1 \text { child } \\
>1 \text { child }\end{array}$ & 0.670 & 0.015 & 0.246 & 0.013 & 0.052 & 0.924 \\
\hline
\end{tabular}

Table 5 Length of Time Diagnosed with the Needs of Parents of School-Aged Children with Thalassemia Major in West Java

\begin{tabular}{lcccccc}
\hline \multicolumn{1}{c}{ Variable } & $\begin{array}{c}\text { Needs of } \\
\text { Information }\end{array}$ & $\begin{array}{c}\text { Needs of } \\
\text { Professional }\end{array}$ & $\begin{array}{c}\text { Needs of } \\
\text { Social }\end{array}$ & $\begin{array}{c}\text { Needs of } \\
\text { Emotional }\end{array}$ & $\begin{array}{c}\text { Needs of } \\
\text { Financial }\end{array}$ & $\begin{array}{c}\text { Needs of } \\
\text { Spiritual }\end{array}$ \\
\hline Length of Time & $\mathrm{r}=0.170$ & $\mathrm{r}=0.127$ & $\mathrm{r}=0.222$ & $\mathrm{r}=0.265$ & $\mathrm{r}=0.202$ & $\mathrm{r}=0.157$ \\
Diagnosed & $\mathrm{p}=0.047$ & $\mathrm{p}=0.142$ & $\mathrm{p}=0.010$ & $\mathrm{p}=0.002$ & $\mathrm{p}=0.018$ & $\mathrm{p}=0.069$ \\
\hline
\end{tabular}

Table 6 The Significant Factors Related to the Needs of Parents of School-Aged Children with Thalassemia Major in West Java

\begin{tabular}{llcccc}
\hline \multicolumn{1}{c}{ Factors } & \multicolumn{1}{c}{ Needs } & B & Wald & p-Value & OR (CI 95\%) \\
\hline The Number of & Emotional & 1.385 & 6.038 & 0.014 & $3.995(1.324-12.060)$ \\
Thalasemia Children & Financial & 1.153 & 3.383 & 0.024 & $3.167(1.165-8.607)$ \\
Gender & Information & 2.639 & 22.090 & 0.000 & $13.997(4.657-42.069)$ \\
& Professional & 1.332 & 7.943 & 0.005 & $3.790(1.500-9.572)$ \\
& Social & 1.288 & 7.865 & 0.005 & $3.625(1.474-8.918)$ \\
& Spiritual & 1.411 & 9.790 & 0.002 & $4.100(1.694-9.922)$ \\
\hline
\end{tabular}

It can be seen from the table 1 above more than a half of parents are 26-45 years old $(52.2 \%)$. Mothers tended to accompany children more during thalassemia $(75.0 \%)$ compared to fathers $(25.0 \%)$. The majority of parents' education is on the elementary level $(58.1 \%)$. Most of the parents get income less than $\mathrm{Rp} 2,250,000$ or below the West Java RMW (71.3\%). The majority of parents have one child with thalassemia (80.9\%).

The time period diagnosed is an average of 7.5 years with only a year diagnosed and a maximum of 12 years with an average and standard deviation of $7.5 \pm 2.85$.

Based on the table 3 above, the needs of spiritual (58.8\%) and social $(58.1 \%)$ were the two highest of the parents' needs, follows the need of information $(55.9 \%)$, 
emotional $(53.7 \%)$ and for the two lowest of parents' needs were financial $(49.3 \%)$, and professional $(45.6 \%)$.

Based on the table 4 above shows that the parents' age is related to the needs of information and professional with $(\mathrm{p}<0.05)$. The gender has a relationship with each domain of parents' needs except emotional needs. Moreover, education and income factors have a relationship to each domain of parents' needs except professional needs ( $p$ $<0.05$ ). Interestingly, the number of having a thalassemic child is the most related factor to emotional and financial needs, while others: the needs of information, professional, social and spiritual are significantly related to the gender of parents.

It can be seen from table 5 above there is a relationship between the length of time diagnosed with the needs of parents of schoolaged children with thalassemia major, except for professional and spiritual needs.

Table 6 The Significant Factors Related to the Needs of Parents of School-Aged Children with Thalassemia Major in West Java

The table 6 above illustrates result of multivariate analysis which indicates the variables that most related to the needs of parents of school-aged children with thalassemia major, based on the p-value and the Odd Ratio (OR) value: more than one thalassemia children who need emotional support more than 3,995 times and needs of financial more than 3,167 times compared to only one child thalassemia. Furthermore, female parents tend to need of information support was about13,997 times, professional needs of 3,790 times, social needs of 3,625 times and spiritual needs 4,100 times compared to male parents.

\section{Discussion}

So far to our knowledge, this is the first study conducted in multisites in West Java to explore predicting factors that correlated to the needs of thalassemic child parents. The findings of this study found that the highest needs of parents are spiritual needs. Thalassemic children need a life-long of treatments such as regular blood transfusions and iron chelation therapy (Mediani et al, 2017; Pillitteri.,
2010). This such long treatments may cause negative impacts on thalassemic children and their families (Prasomsuk, Jetsrisuparp, Ratanasiri, \& Ratanasiri, 2007). Fulfilment of spirituality in parents provides strength and helps them in controlling the problems and their burdens that occur which are related to their children's illness (Mediani et a.l, 2017; Pillitteri., 2010; Sujana, Fatimah \& Hidayati, 2017). Spirituality is a source for someone who is religious as his coping (Frey, Daaleman., \& Peyton., 2005).

The meaning of spirituality is finding out whether parents can find the meaning and purpose of life when their children are sick. If parents cannot find the meaning and purpose of their life, as a nurse, they can help parents find the meaning of spirituality and encourage parents to use their spirituality as a strength in facing problems (Nur'aeni, Ibrahim \& Agustina, 2013). The conditions faced by parents make their lives not as normal as before children suffering from thalassemia, thus, by these conditions parents can actually take wisdom in their lives (Hexem et a.1, 2011). Previos research conducted by Nuraeni, Nurhidayah, Hidayati, Sari and Mirwanti (2015) showed that almost all respondents in this study chose and knew the spiritual needs by finding the meaning of pain and suffering.

Age affects a person in expressing feelings and using coping through illness (Viedebeck., 2008). Usually, anxiety at a young age is easier to emerge from at an older age, but can also occur otherwise. The anxiety that occurs in the elderly can arise due to past experience of the same thing before (Kaplan \& Saddock, 2010). Research conducted by McKenna, Coller, Hewitt and Blake (2010) found that older parents want more information support from health professionals in making decisions. The older the age of parents will experience a physical decline so that it has an influence in providing information (Fahra, Widayati \& Sutawardana, 2017; Kaplan \& Saddock, 2010). Therefore, the parents' physical decline limits parents in seeking information so that it requires information support, in contrast to young age who can seek information from various sources.

Fathers are more responsible for family finances, this is related to the culture that 
the main breadwinner is a father (Handian, Widjajanto \& Sumarni, 2017). In this study, most mothers did not work or as housewives and rely solely on income from their husbands. This makes the fathers have a greater financial burden so the financial support is more needed for the fathers than the mothers $(67.6 \%)$. Meanwhile, mothers have a more sensitive feeling to their emotions that affect their emotional and psychologically status, they will easy to get anxiety and stress (Kaplan \& Saddock, 2010). As Mediani et al. (2017) indicated that all mothers in their study experienced more fear and sadness because they felt worries and uncertainty about the future of their thalassemic child. Similarly, Oers et al. (2014) found that parents who have children with chronic diseases, especially mothers report high levels of anxiety and depression.

Interestingly, this current study is different from previous research conducted by Mundy (2010) that indicated the needs of mothers were not significantly different from fathers. In Asian culture, especially in Indonesia, fathers are required to remain calm in an emotional state and must control their emotions, so they are not free to express emotions (Kati, Opod \& Pali, 2018). Although the gender in this study did not relate to emotional needs, the results of cross-tabulation showed that mothers needed high emotional needs $(57.8 \%)$. Children with thalassemia pose an emotional burden to mothers because they are pregnant and raise children so they have stronger relationships with children.

Education is foundation for people to drive their ability in improving their health status; it enables people to be more productive to earn a better quality of life (Mediani, 2014). Low educated people tend to be less able to use effective and constructive coping compared to higher education levels so that they need the support of other coping sources (Davies et al, 2011; Notoatmodjo, 2007). Higher education will influence the thinking of parents so it is more rational in dealing with problems. People with having adequate knowledge and education tend to have effective and constructive coping when facing problems that will more easily overcome anxiety and fulfil their emotional needs (Mediani, 2014; Notoatmodjo, 2007). Results of this current study showed that some parents had low level education background, they finished their study from primary education (elementary/ middle school) only and the need of emotional support as much as $67.1 \%$. This study finding is in line with research conducted by Cheah, Ling and Chang (2015) which identified that low education background (elementary school education) was significantly associated with non-fulfilment of needs ( $p<0.01)$.

Literature reveals that people who have low basic education are more often faces spiritual distress (Caldeira, Csrvalho \& Viera., 2014). Meanwhile, previous study found that people with having higher education tends to have more experience with spiritual needs (Forouzi, Tirgari, Safarizadeh, \& Jahani, 2017). Findings of this current study indicated that parents with having higher education are more effective in using spirituality than people with having low education. This current research is concurrent with earlier study conducted by Rezaei, Fatemi, Givari and Hoseyni (2009) which showed that the level of education is related to spirituality, the lower the level of education, the greater the spiritual needs.

High income tends to get good tools in finding information to increase their knowledge (Thavorncharoensa et al, 2010; Novrianda, Yeni \& Asterina., 2014). Results of study by Thavorncharoensa et al (2010) stated that income affects information needed by parents, both from visual audio or print media. According to Darmojo and Hadi (2006) people who did not work showed little change in the level of knowledge compared to people who work because they are more active outside so they get a lot of information from friends in their work environment. Previous study conducted by Novrianda, Yeni and Asterina (2014) showed that income has a meaningful relationship with knowledge $(p=0.006)$. High economic status has better opportunity to get whatever is needed including information networks, while parents with low economic status must think about spending money because basic needs are more important to them. Health professionals also tend to assume that lowincome parents are able to understand and use information properly (Gallo, Knafl \& Angst., 2009). Another study conducted by 
Alam (2007) found that parents with low economic status are associated with not meeting financial needs, especially medical expenses. In this study, parents said that even though the cost of treating thalassemia was borne by the Social Security Organizing Agency (BPJS), but parents with low income said they had to bear other costs such as transportation because they used motorcycle taxis, public transportation and minibuses to the hospital.

Social support is very important for lowincome individuals because it helps them overcome financial problems (Documet et al, 2015; Mediani et al, 2017). The family financial burden on health care can be reduced by family support (Golics, Khurshid, Basra, Salek \& Finlay, 2013). The research conducted by Mashayekhi, Jozdani, Chamak and Mehni (2016) found that low income can significantly influenced social support. Results of this study is concurrent with this current study that parents with low income required higher social support. This current study fundings are supported by otherprevious study conducted by Norberg, Lindblad and Boman (2006), which showed that income was related to social support received by parents $(p=0.012)$. Parents who care for children with chronic diseases and also low-income people will greatly influence their social life, such as interaction with other people in daily activities will be carried out quickly or immediately abandoned even though these activities have not been completed (Golics et al, 2013).

The more number of children, the stress level of parents would be higher because the role that must be done is increased as parents who care for children (Alam, 2007; Mirbehbahani, Salehi, Jahazi, \&Karimi, 2014). Research conducted by Mirbehbahani, Salehi, Jahazi and Karimi (2014) showed that having more than one child thalassemia was associated with depression in the elderly ( $p$ $=0.01$ ). Parents who have two thalassemia children feel sad and disappointed hoping that their other children will not suffer from thalassemia. Parents with two or more thalassemia children have greater pressure than parents who have one child with thalassemia major (Sultana, Humayun, Humayun \& Zafar, 2016).
The financial burden becomes a problem in the family when treating children with chronic diseases, especially genetic diseases (Mediani et a, 2017). This means parents who have more than one child are influential in the family, especially low socio-economic groups (Wahab et al, 2011). The number of children affects the family finances because more and more children are cared for causing greater costs.

Based on bivariate tests showed there was no relationship between the number of thalassemia children and the spiritual needs of parents but the results of cross-tabulation showed that parents who have more than one thalassemic child need spiritual support. Everyone depends on spiritual and religious support in controlling their emotions (Golics et al, 2013). In this study, the mothers always cried while praying and wondered why their child must suffer from thalassemia and be different from other children.

The longer caring for children with thalassemia, the more obstacles faced by parents and that such bariers must be overcome during caring for thalasemic children because parents will often feel anxious about the uncertain condition of the child (Mediani et al, 2017; Rachmawati, Ranuh \& Arief, 2016). Infact the treatment of thalassemic children need a life-long treatments of regular blood transfusion and iron chelation therapy, however there is no certainty of recovery also makes parents feel anxious (Mediani et al, 2017; Pouraboli et al, 2015). Similarly, Norberg and Boman (2008) found that anxiety and depression that occur in older people still occured after 2.5 years since being diagnosed and $12 \%$ of parents with having children diagnosed of cancer more than five years continue to report the same thing. This is due to parents's coping was not effective in overcoming their psychological distress and fear knowing their child illness. In addition, long treatments of thalassemia such as routine transfusions cause negative impacts on thalassemic children. Changes in face shape, skin colour, splenomegaly and growth delay in their children and delaying puberty in children as common problems faced by thalassemic children as side effect of long routine transfusion that will cause concern to parents (Kahouei, Kazemzadeh, 
Henny Suzana Mediani: Factors Related to The Needs of Patients Having School Age Thalassemic

Zadeh \& Ahmadi, 2016; Mediani et al, 2017; Norberg, \& Boman, 2008; Shosha \& Kalaldeh., 2017; Shosha, 2014).

Parents need information not only at the beginning of the diagnosis but continue during childcare (Mediani et al, 2017; Ririnisahawaitun, Prabandari, \& Gamayanti, 2015). Research conducted by Lee, Nelson, Thompson and Donovan (2016) showed that the length of time diagnosed is related to information needs. According to Dahnil, Mardhiyah and Widianti's study (2017) that more than half of respondents need information regarding thalassemia, treatment and side effects of therapy. Similarly, Mediani et al. (2017) found that all participants in this study needs a lot information regarding the disease and its treatments. Parents still want the latest information about thalassemia such as new treatment options related to chelation and transplantation (Liem et al, 2011).

Acording to Shosha and Kalaldeh (2017) after one year since diagnosis of disease, perceived social support tends to decrease. The immediate family and people provide supports at the beggining of the diagnosis but from time to time the perceived support begins to decrease (Banovcinova \& Baskova, 2014). The longer suffering from the disease makes a person resigned to treatment different from the time span of the sick who still have high expectations of treatment (Satari et al, 2012). Therefore, parents who have long treated thalassemia children need spiritual support because without hope it will cause a loss of enthusiasm and surrender that affects the care of their children (Mediani et al, 2017).

The longer the child is diagnosed, the treatment that has been carried out has been going on for a long time, this makes parents have financial difficulties because of the repeted costs to the hospital (Rijen, Spreeuwenber, Schippers \& Groenewegen, 2013; Satari et al, 2012). Research conducted by Rijen, Spreeuwenber, Schippers and Groenewegen (2013) indicated that the longer the duration of illness is associated with lower opportunities to seek economics, especially parents of thalassemia children in this study some of whom have self-employment such as drivers, farmers and labourers whose income is not fixed monthly.

Based on result of multivariate analysis in this current study to see the most influential variables on the needs of parents thalassemic children can be seen from the value of the Odd Ratio (OR) to the variable $p$-value $<0.05$. Results of multivariate analysis indicated that there are three highest of the parents' needs were related to professional, emotional and financial needs. Interestingly, the most related to gender needs were information needs, professional support, social and spiritual support.

Literature identifies that parents who have more than one child with thalassemia major complain of financial problems in the family (Shosha \& Al Kaladeh, 2017). This happens because of changes in the family economy and impact on the quality of parents in caring for children (Mediani et al, 2017; Shahraki-vahed et al., 2017; Retnaningsih \& Dini, 2016). Some parents with loweconomy have problems with the cost of hospital transportation for routine care and the problem is escalating as the number of thalassemia children increasing (Mediani et al., 2017; Shahraki-vahed et al., 2017).

Parents who have more than one child with chronic conditions feel their welfare is lower, less optimistic, distress and even depressed (Ekas, Whitman \& Shivers, 2009; Saldanha, 2013). For instance, Saldanha (2013) found that parents who have more than one thalassemic child are significantly experienced stress. Similarly, Ismail et al (2013) identified that parents with more than one child with thalassemia faced more problems due to increased physical and mental stress that affect their quality of life.

The next one, gender was also identified as the most related factor to the needs of parents of thalassemic children in this current study. Spending time with friends and talking with parents of thalassemia is the most important thing for mothers compared to fathers. Emotional support is usually obtained from friends and family, while information support involves health professionals (Mediani et al, 2017; Requena, Arnal, \& Gil, 2015). This current research is in line with the research conducted by Maunder (2012) which showed that in a multivariate manner, parent gender is the factor most related to parental needs (OR 3.6). Mothers said she wanted to get more support than fathers. As the primary 
caregiver, the mother's responsibility to bring her child to undergo treatment for a long time and the mother must also care for other children so that they need a source of support, both emotional, mental and social.

Limited information obtained by parents and poor communication from the nurses causes delays in parents' ability to care for children (Pelentsov, Fielder, Laws \& Esterman, 2016). Support of physicians, nurses, psychologists/psychiatrists and nutritionists is the most important source for parents during treatment (Baer, 2013; Requena, Arnal \& Gil, 2015). During the treatment is the right time to receive emotional support and information as one of the interventions of health professionals (Mediani et al, 2017: Requena, Arnal, Gil, 2015). It is therefore nurses as patient advocate should more aware about the patients and their family needs. Nurses need to maintain a good communication and provide cointinus supports to their thalassemic patients and their family. Furthermore, it is necessary to provide a consultation room in thalassemic clinic so parents will feel more compfortable and that it can guarantee its privacy and be more open to nurses.

\section{Conclusion}

According to findings of this current study can be concluded as follows:

1. The parents' age is related to the needs of information and professional. The gender has a relationship with each domain of parents' needs except emotional needs. Furthermore, education and income factors have a relationship to each domain of parents' needs except professional needs. The number of children with thalassemia major is related to social, emotional and financial needs. The time period of being diagnosed is related to information, social, emotional and financial needs but is not related to professional and spiritual needs.

2 . The number of children with thalassemia major is the most related factor to emotional and financial needs, while others: needs of information, professional, social and spiritual are significantly related to the gender of parents.
The results of this study are expected to be input as consideration in providing nursing care to parents who have children with thalassemia.

1) Nurses are expected to play an active role as educators or consultants because most parents of children with thalassemia really need information and emotional support in child care. Therefore, consultation at any time is needed to support the parents' role by providing appropriate knowledge about treatment and care that is being undertaken. In addition, there are specialized nurses who can provide genetic counselling. Nursing services can also provide education on safe contraceptive methods. The implementation of prenatal diagnosis can also be considered in the prevention of thalassemia.

2) Providing spiritual, emotional and financial support to foster a sense of optimism and expectations of parents is needed by empowering parents in finding various sources of support that can strengthen coping strategies, both family and fellow parents who have children with thalassemia and other support groups, and looking for various family financial resources related to treatment, both formal and non-formal institutions such as those provided by the government with the use of BPJS and thalassemia foundations.

\section{For the management of hospitals}

It is expected to increase the role of nurses as educators and consultants who are directly faced with every parent who has children with thalassemia by socialising the importance of meeting the needs of parents of children with thalassemia major as an intervention in implement appropriate nursing care so parents can provide caring for their children with thalassemia optimally.

\section{For Further Researchers}

Future research is needed to examine other factors in each domain of parents' needs such as marital status, family form, coping, age of the child, and conduct further research by comparing differences in needs between fathers and mothers of school-aged children with thalassemia in helping meet their needs to improve the quality of services, especially pediatric nursing. 
Henny Suzana Mediani: Factors Related to The Needs of Patients Having School Age Thalassemic

\section{References}

Adioetomo, S.M., \& Samosir, O.B. (2010). Dasar-dasar demografi 2. (Demographics basics 2. 2nd edition). Edisi ke-2. Jakarta: Salemba empat.

Alam, N. (2007). Unmet Need for Additional Medical Care for Sick Children In Mother's View in Rural Bangladesh: Implications for Improving Child Health Services. Journal biosocial Science, 39, 769-778. Doi: 10.1017/ S002193200700185X.

Asmadi. (2008). Teknik Prosedural Keperawatan: Konsep dan Aplikasi Kebutuhan Dasar Klien. (Nursing Procedural Techniques: Concepts and Applications of Client's Basic Needs). Jakarta: Salemba Medika.

Astarani, K., \& Siburian, G.G. (2016). Gambaran Kecemasan Orang Tua Pada Anak Dengan Thalasemia. (Anxiety Description of Parents in Children with Thalassemia). Jurnal STIKES, 9(1).

Baer, K. (2013). A Guide to Living with Thalassemia. Retrieved from http:// www.cooleysanemia.org/updates/pdf/ GuideToLivingWithThalassemia.pdf.

Banovcinova L., \& Baskova, M. (2014). Role of the family, friends and significant others in providing social support and enhancing quality of life in cancer patients. Intrenational Conference Society Healt. Welfare. DOI: 10.1051/shsconf/20163000020.

Cheah, W.L., Ling, N.C., \& Chang, K.H. (2015). The supportive care needs for prostate cancer patients in Sarawak. China Clinnical Oncology, 5(1):7. doi: 10.3978/j.issn.23043865.2016.02.01.

Dahnil, F., Mardhiyah, A., \& Widianti, E. (2017). Kajian Kebutuhan Supportive Care Pada Orang Tua Anak Penderita Talasemia. (Supportive Care Needs Assessment for Parents of Children with Thalassemia). Nurse Line Journal,2(1). p-ISSN 2540-7937 e-ISSN 2541-464X.
Davies, N. M., Dickson, M., Davey Smith, G., van den Berg, G. J., \& Windmeijer, F. (2018). The Causal Effects of Education on Health Outcomes in the UK Biobank. Nature human behaviour, 2(2), 117-125. doi:10.1038/s41562-017-0279-y.

Documet, P., Bear, T.M., Flatt, J.D., Macia, L., et al. (2015). The Association of Social Support and Education with Breast and Cervical Cancer Screening. Health Education \& Behaviour, 42(1) 55-64. DOI: $10.1177 / 1090198114557124$.

Ekas, N.V., Whitman, T.L., \& Shivers, C. (2009). Religiosity, Spirituality, and Socioemotional Functioning in Mothers of Children with Autism Spectrum Disorder. Journal Autism Development Disorder, 39:706-719. DOI 10.1007/s10803-0080673-4.

Fahra, R.U., Widayati, N., \& Sutawardana, J.H. (2017). Hubungan Peran Perawat Sebagai Edukator Dengan Perawatan Diri Pasien Diabetes Melitus Tipe 2 Di Poli Penyakit Dalam Rumah Sakit Bina Sehat Jember. (The Relationship between the Role of Nurses as Educators and Self-Care for Type 2 Diabetes Mellitus Patients in Internal Medicine Polyclinic Bina Sehat Hospital, Jember). Nurse Line Journal ,2 (1), Mei 2017 p-ISSN 2540-7937 e-ISSN 2541-464X.

Fitch, M.I. (2008). Supportive care framework. CONJ, 18(1): 6-24.

Forouzi, M.A., Tirgari, B., Safarizadeh, M.H., \& Jahani, Y. (2017). Spiritual Needs and Quality of Life of Patients with Cancer. Indian Journal of Palliative Care, 23(4): 437444. https://dx.doi.org/10.4103\%2FIJPC. IJPC 5317.

Frey, B.B., Daaleman, T.P., \& Peyton, V. (2005). Measuring a dimension of spirituality for health research. Research on Aging, 27(5), 556-577. Doi: 10.1177/0164027505277847.

Galanello, R., \& Origa, R. (2010). BetaThalassemia. Orphanet Journal of Rare Diseases, 5:11. 
Henny Suzana Mediani: Factors Related to The Needs of Patients Having School Age Thalassemic

Gallo, A.M., Knafl, K.A., \& Angst, D.B. (2009). Information Management in Families Who Have a Child with a Genetic Condition. Journal of Pediatric Nursing,24(3). doi:10.1016/j.pedn.2008.07.010.

Golics, C.J., Khurshid, M., Basra, A., Salek, M.S., \& Finlay, A.Y. (2013). The impact of patients' chronic disease on family quality of life: an experience from 26 specialties. International Journal of General Medicine ,6, 787-798. http://dx.doi.org/10.2147/IJGM. S45156.

Habeeb, A.D., Hassan, M.K., \& Ahmed, B. A. A. (2015). Psychosocial Impact of Sickle Cell Disease On Families in Basra, Southern Iraq; An Experience of Caregivers. International Journal of Medicine and Pharmaceutical Sciences (IJMPS), 5(4), 41-52.

Hamzah, I.F., Dewi, E.K., \& Suparno (2014). Makna Sakit Pada Penderita Penyakit Jantung Koroner: Studi Fenomenologis. (Meaning of Pain in Patients with Coronary Heart Disease: A Phenomenological Study). Jurnal Psikologi Undip, 13(1), 1-10.

Handian, F.I., Widjajanto, P.H., \& Sumarni, (2017). Motivasi, hambatan dan strategi orangtua keluarga miskin dalam merawat anak dengan leukemia limfoblastik akut (LLA). (Motivation, Barriers And Strategies Of Parents Of Poor Families In Caring For Children With Acute Lymphoblastic Leukemia (LLA)). Jurnal Care, 5(1).

Hexem, K.R., Mollen, C.J., Carroll, K., Lanctot, D.A., \& Feudtner, C. (2011). How parents of children receiving pediatric palliative care use religion, spirituality, or life philosophy in tough times. Journal of Palliative Medicine, 14(1), 39-44. Doi: 10.1089/jpm.2010.0256.

Ishfaq, K., Bhatti, R., \& Bin Naeem, S. (2014). Mothers' awareness and experiences of having a thalassemic child: A qualitative approach. In: Proceedings of Socioint14 International Conference on Social Sciences and Humanities, Istanbul, Turkey, 8-10 September (2014), pp. 660-669. Turkey: International Organization Center of
Academic Research.

Ismail, M., Chun, C.Y., Yusoff, N.A.M., Shahar, S., Manaf, Z.A., et al. (2013). Quality of life among thalassaemia children, adolescent and their caregivers. Sains Malaysiana, 42(3), 373-380.

Kaplan, I.H., Sadock, B.J., \& Grebb, J.A. (2010). Sinopsis psikiatri ilmu pengetahuann perilaku psikiatri klinis. (Synopsis of Psychiatry, Behavioral Science of Clinical Psychiatry). Tangerang: Binarupa Aksara.

Kati, R.K., Opod, H., \& Pali, C. (2018). Gambaran emosi dan tingkat kecemasan pada pasien hipertensi di Puskesmas Bahu. (Emotions and Anxiety Levels in Hypertension Patients at Bahu Health Center). Jurnal e-Biomedik (eBm), 6(1).

Kemenkes RI. (2017). Skrining penting untuk cegah thalassemia. (Important Screening to Prevent Thalassemia). Retrieved from http://www.depkes.go.id/article/ view/17050900002/skrining-penting-untukcegah-thalassemia.html.

Kerr, L.M.J., Harrison, M.B., Medves, J., Tranmer, J.E., \& Fitch, M.I. (2008). Understanding the supportive care needs of parents of children with cancer: An approach to local needs assessment. Journal of Pediatric Oncology Nursing, 24(5), pp 279-293.

Kim, Y., Kashy, D.A., Spillers, R.L., \& Evans, T.K. (2010). Needs assessment of family caregivers of cancer survivors: Three cohorts comparison. Psycho-Oncology, 19, 573-582. DOI: 10.1002/pon.1597.

Klaassen, R., \& Shaw, N.T. (2011). Understanding the health impact of caregiving: a qualitative study of immigrant parents and single parent of children with cancer. Quality Life Research, 21, 15951605. DOI: 10.1007/s11136-011-0072-8.

Kuo, D.Z., Houtrow, A.M., Arango, P., Kuhlthau, K.A., Simmons, J.M., \& Neff, J.M. (2012). Family-centered care: Current application and future direction in pediatric 
Henny Suzana Mediani: Factors Related to The Needs of Patients Having School Age Thalassemic

health care. Maternal Child Health Journal, 16, 297-305. DOI: 10.007/s10995-011-0751.

Kyle, T., \& Carman, S. (2014). Buku ajar keperawatan pediatri. (Pediatric nursing Textbook). Jakarta: EGC.

Lee, M.S., Nelson, A.M., Thompson, L.M.A., \& Donovan, K.A. (2016). Supportive care needs of oral cancer survivors: Prevalence and correlates. Oral Oncology, 53, 85-90.

Liem, R.I., Gilgour, B., Pelligra, S., Mason, M., \& Thompson, A. (2011). impact of thalasemia on southeast asian and asian indian families in the United States: A qualitative study. Ethnicity \& Disease, 21, 361-369, Summer 2.

Marcdante, K.J., Kliegman, R.M., Jenson, H.B., \& Behrman, R.E. (2011). Nelson ilmu kesehatan anak esensial (Edisi ke-6). (Nelson's Essential Child Health Sciences sixth edition). Singapura: Saunders Elsevier.

Maunder, K. (2012). Investigating supportive care needs of parents of children with cancer: Is a parent support group intervention a feasible solution?. A thesis of Institute of Medical Sciences University of Toronto. Retrieved from https://tspace. library.utoronto.ca/bitstream/1807/33444/3/ Maunder_Kristen_M_201211_MSc_thesis. pdf.

McKenna, K., Coller, J., Hewitt, M., \& Blake, H. (2010). Parental involvement in paediatric cancer treatment decisions. European Journal of Cancer Care, 19(5), pp 621-630.

Mediani, H.S., Nurhidayah, I., Mardhiyah,A., \& Panigoro, R. (2017). Indonesian mothers' and concerns about having a thalassemic child and its treatment: An exploratory qualitative study. International Journal of Nursing Care, 1(2), 1-7.

Mediani, H. S. (2014). Indonesian nurses' management of pain in children: A grounded theory study. Doctoral thesis, Curtin University. Retrieved from http://tinyurl. com/mpelq6k.
Mirbehbahani, N., Salehi, M., Jahazi, A., \& Karimi, M. (2014). Prevalence and intensity of depression in mothers of chi ldren with beta-thalassemia major in Talghani Hospital of Gorgan, Iran. JKIMSU, 3(1).

Mundy, C.A. (2010). Assessment of family needs in neonatal intensive care units. American Journal of Critical Care, 19(2). Doi: 10.4037/ajcc2010130.

Nafafi, K., Borhani, F., Rabari, E., \& Sabzevari, S. (2011). The effect of familycentered empowerment model on the mother knowledge and attitudes about thalassemia disorder. Iran Journal Pediatric Hematologi Oncologi, 1, 98-103.

Norberg, A.L., \& Boman, K.K. (2008). Parent distress in childhood cancer: A comparative evaluation of posttraumatic stress symptom, depression and anxiety. Acta Oncologica, 47, 267-274. Doi: 10.1080/02841860701558773.

Norberg, A.L., Lindblad, F., \& Boman, K. (2006). Support-seeking, perceived support, and anxiety in mothers and fathers after children's cancer treatment. PsychoOncology, 15, 335-343.

Novrianda, D., Yeni, F., \& Asterina. (2014). Hubungan karakteristik ibu dengan pengetahuan tentang penatalaksanaan diare pada balita. (Relationship between Mother Characteristics and Knowledge about Diarrhea Management in Toddlers). Ners Jurnal Keperawatan, 10(1), 159 - 166.

Nur'aeni, A., Ibrahim, K., \& Agustina, H.R. (2013). Eksplorasi makna spiritualitas pada klien dengan sindrom koroner akut yang menjalani perawatan di ruang intensif jantung. (Exploration of the Meaning of Spirituality in Clients with Acute Coronary Syndrome who are undergoing treatment in a cardiac intensive care unit). Jurnal Keperawatan Padjadjaran, 1(2), 2338-5324.

Nur'aeni, A., Nurhidayah, I., Hidayati, N., Sari, C.W.M., \& Mirwanti, R. (2015). Kebutuhan spiritual pada pasien kanker. (Spiritual Needs of Cancer Patients). Jurnal Keperawatan Padjadjaran, 3(2). 
Henny Suzana Mediani: Factors Related to The Needs of Patients Having School Age Thalassemic

Oers, H.A., Tacke, C.E., Haverman, L., Kuipers, I.M., Maurice-Stam, H., Kuijpers, T.W., \& Grootenhuis, M.A. (2014). Health related quality of life and perceptions of child vulnerability among parents of children with a history of Kawasaki disease. Acta Paediatr, $103,671-677$.

Pelentsov, L.J., Dip, G., Laws, T.A., \& Esterman, A.J. (2015). The Supportive Care Needs of Parents Caring for A Child with A Rare Disease: A Scoping Review. Disability and Health Journal, 8, 475-491. DOI: 10.1016/j.dhjo.2015.03.009.

Pelentsov, L.J., Fielder, A.L., Laws, T.A., \& Esterman, A.J. (2016). The Supportive Care Needs of Parents with A Child with A Rare Disease: Results of An Online Survey. BMC Family Practice, 17, 88. DOI 10.1186/ s12875-016-0488-x.

Pillitteri A (2010) Maternal and child health nursing: Care of the childbearing and childrearing family. Lippincott Williams and Wilkins.

Potts, N.L., \& Mandleco, B.L. (2007). Pediatric nursing: Caring for children and their families (2nd Ed.). New York: Thomson Coorporation.

Rachmawati, P.D., Ranuh, R., \& Arief, Y.S. (2016). Perilaku ibu dalam pemenuhan kebutuhan asah, asih dan asuh anak dengan leukemia. (Mother Behavior in Fulfilling the Needs of Educating, Loving and Caring for Children with Leukemia). Jurnal Ners, 11(1), 63-72.

Retnaningsih, D., \& Dini, I.K. (2016). Analisa dukungan keluarga dengan beban orangtua dalam merawat anak penyandang cacat tingkat SD di SLB Negeri Semarang. (Analysis of Family Support with the Burden of Parents in Caring for Children with Disabilities at SD Level in Public Special School Semarang). Retrieved fromfile://C:/ Users/ASUS/Downloads/364-882-1-PB.pdf.

Requena, G.C., Arnal, R.B., \& Gil, F. (2015). The influence of demographic and clinical variables on perceived social support in cancer patients. Revista de Psicopatología journal Psicología Clínica, 20, 25-32, 2015. doi: 10.5944/rppc.vol.1.num.1.2015.14404.

Rijen, M., Spreeuwenber, P., Schippers, J., \& Groenewegen P.P. (2013). The importance of illness duration, age at diagnosis and the year of diagnosis for labour participation chances of people with chronic illness: results of a nationwide panel-study in the Netherlands. BMC Public Health, 13, 803 http://www. biomedcentral.com/1471-2458/13/803.

Ririnisahawaitun, Prabandari, Y.S., \& Gamayanti, I.L. (2015). Kebutuhan dan pemberian informasi oleh perawat pada orangtua dari remaja kanker. Seminar dan Workshop Nasional Keperawatan "Implikasi Perawatan Paliatif pada Bidang Kesehatan". (Information Needs and Information Provision by Nurses for Parents of Cancer Adolescents. National Nursing Seminar and Workshop "Implications of Palliative Care in the Health Sector)." Retrieved fromfile:///C:/ Users/ASUS/Downloads/778-1383-1-PB. pdf.

Regar, J. (2009). Aspek genetik talasemia. (Genetic Aspects of Thalassemia). Jurnal Biomedik, 1(3), 151-158.

Rezaei, M., Seyed Fatemi, N., Givari, A., \& Hoseyni, F. (2009). Spiritual in cancer patients receiving chemotherapy. Hayat, 4(3, 4), 33-39. [in Persian].

Saldanha, S.J. (2013). Stress and Coping among Parents of Children Having Thalassemia. International Journal of Science and Research (IJSR), 2319-7064.

Shahraki-vahed, Mohammadreza, Firouzkouhi, Abdolghani, Abdollahimohammad, \& Ghalgaire, J. (2017). Lived experiences of Iranian parents of beta-thalassemia children. Journal of Multidisciplinary Healthcare, 10, 243-251.

Shosha, G.M.A. (2014). Needs and concern of jordanian mother with thalassemic children: A qualitative study. Journal of American Science, 10(1), 11-16. 
Henny Suzana Mediani: Factors Related to The Needs of Patients Having School Age Thalassemic

Shosha, G.A., \& Kalaldeh, M.A. (2017). Challenges of having a child with thalassaemia major: A phenomenological study. Journal of Research in Nursing, $0(0)$ 1-12. DOI: $10.1177 / 1744987117724497$.

Sujana, E., Fatimah, S., \& Hidayati, N.O. (2017). Kebutuhan spiritual keluarga dengan anak penderita penyakit kronis. (Spiritual Needs of Families with Chronic Illness Children). Jurnal Pendidikan Keperawatan Indonesia, 3(1), 47-56.

Sultana, R., Humayun, S., Humayun, S., \& Zafar, U. (2016). Psychosocial problems in parents of thalassaemia children. J. Soc. Obstet. Gynaecol, 6(2).

Suza, D.E. (2017). Family-centered care model untuk menurunkan dampak hospitalisasi anak dengan penyakit kanker di Medan, Sumatera Utara. (FamilyCentered Care Model to Reduce the Impact of Hospitalization of Children with Cancer in Medan, North Sumatra). IDEA Nursing Journal, VI(1), 15-24, e-ISSN: 2580-2445.

Viedebeck, S.L. 2008. Buku ajar keperawatan jiwa. (Mental Nursing Textbook). Jakarta: EGC .

Wacharasin, C.P., Phaktoop, M., \& Sananreangsak, S. (2015). A family empowerment program for families having children with thalassemia, Thailand. Nursing and Health Science, 17, 387-394. DOI: 10.1111/nhs.12201.

Wahab, J.A., Naznin, M., Nora, M.Z., Suzanah, A.R., et al. (2011). Thalassaemia: A study on the perception of patients and family members. Medical Journal Malaysia, 66(4).

Wilder, S.K. (2010). Polytrauma family needs assessment. Theses and Dissertations Virginia Commonwealth University. Retrieved fromhttp://Scholarcompass.vcu. edu/etd/2051.

Winstanley, J., Simpson, G., Tate, R., \& Myles, B. (2006). Early indicators and contributors to psychological distress in relatives during rehabilitation following severe traumatic brain injury: Findings from the brain injury outcomes study. Journal of Head Trauma Rehabilitation, 6, 453-466. 